\title{
Glucose and Lipid Lowering Potentials of Heliotropium indicum L. Leaves in Alloxan-Induced Hyperglycaemic Rats
}

\author{
Rasheed B. IBRAHIM ${ }^{1,2}$, Jubril O. AKOLADE ${ }^{2,3 *}$, Raliat A. \\ ALADODO $^{1}$, Omoaruemike E. OKEREKE $^{3}$, Sarah A. AKANDE ${ }^{3}$ \\ ${ }^{1}$ Kwara State University, Department of Biosciences and Biotechnology, Malete, Nigeria; ibrahimrasheedb@gmail.com \\ ${ }^{2}$ University of Ilorin, Department of Biochemistry, Ilorin, Nigeria; jubrilakolade@gmail.com (*corresponding author) \\ ${ }^{3}$ Sheda Science and Technology Complex, Biotechnology Advanced Research Centre, Abuja, \\ Nigeria;oe_okereke@yahoo.com; sarafenwa@yahoo.com
}

\begin{abstract}
The antidiabetic potentials of Heliotropium indicum L. leaf aqueous (HILA) extract used for the management of diabetes by Traditional Medicinal Practitioners (TMPs) in Nigeria was assessed. Alloxan (ALX)-induced hyperglycaemic rats were orally administered with known folkloric dosage of 30 and $75 \mathrm{mg} / \mathrm{kg}$ b. wt. of HILA extract, once a day, for 14 days. Fasting blood glucose (FBG) levels were monitored and pancreatic histology was examined. Net hepatic glycogen (GLY) concentration and lipid profiles were also determined. Prior to treatment, ALX-induced hyperglycaemia $(\geq 250 \mathrm{mg} / \mathrm{dL})$ was established in rats. Oral administration of 30 and $75 \mathrm{mg} / \mathrm{kg}$ b. wt. HILA extract to diabetic rats for 14 days caused significant reduction in FBG to baseline values observed in non-diabetic conditions. Treatment with HILA extract also showed improvement in lipid abnormalities observed in hyperglycaemic condition, levels of triglyceride, total cholesterol and LDLcholesterol were significantly reduced and HDL-cholesterol increased resulting in improved artherogenic index. Hepatic GLY concentration was significantly increased in diabetic rat treated with the extract. Histological examinations showed degenerated and sparse pancreatic islets $\beta$-cells in non-treated diabetic rat, whereas microscopy of treated rats showed mild to normal architecture with enriched $\beta$-cells. Preliminary phytochemical profiling of the extract revealed the presence of alkaloids $(2.54 \mathrm{mg} / \mathrm{g})$, saponins $(0.28 \mathrm{mg} / \mathrm{g})$, phenols $(0.04 \mathrm{mg} / \mathrm{g})$ and anthraquinones $(0.01 \mathrm{mg} / \mathrm{g})$. Results from this study revealed that the aqueous leaf extract of $H$. indicum possesses not only antihyperglycaemic, but also antidyslipidemic activities, that may prove to be of clinical importance in the management of diabetes and associated secondary complications.
\end{abstract}

Keywords: blood glucose, diabetes, Heliotropium indicum, medicinal plants, serum lipids

\section{Introduction}

International Diabetes Federation reported that about 387 million people have diabetes and this is projected to ascend to 592 million by 2035. The projected increase in prevalence rate is due to urbanization and associated lifestyle changes, increase in life expectancy at birth of diabetic population, physical inactivity, obesity and possibly a genetic predisposition (Wild et al., 2014). The number of persons living with type 2 diabetes is increasing in every population and $77 \%$ of people with diabetes live in low income and middle income countries (IDF, 2014).

Diabetes results from an alteration in the availability of insulin and/or the inability of the body to utilize the hormone, as well as irregularities in the endocrine system that may involve other hormones (Guthrie and Guthrie, 2009). It is a chronic disease characterized by persistent hyperglycaemia caused by inherited or acquired deficiency of insulin production by pancreatic $\beta$-cells and alterations in the insulin sensitivity of tissues such as muscle, liver and adipose tissue (Adisakwattana et al., 2005).

Diabetes mellitus is often associated with classical characteristic symptoms such as vision blurring, polydypsia, polyphagia and polyuria (Shin et al., 2012). It is associated with reduced quality of life and increased risk factors for mortality and morbidity. The effects of diabetes mellitus include longterm damage, dysfunction and failure of various organs as a result of secondary complications (Oyagbemi et al., 2014). The long-term hyperglycaemia is an important factor in the development and progression of micro- and macro vascular 
complications (Strojek, 2003; Oyagbemi et al., 2014). Dyslipidemia is an important risk factor of vascular complications in diabetes mellitus (Cade, 2008). Abnormal lipid metabolism is common in patients with diabetes causing alterations in lipid profiles (Li et al., 2004). Dyslipidemia results from multiple factors which are either a direct manifestation of defects in insulin action and hyperglycaemia or the obesity/insulin-resistant metabolic disarray which is the source of type 2 diabetes and could lead to lipid abnormalities exclusive of hyperglycaemia (Goldberg, 2001).

Conventionally, type 2 diabetes is treated with synthetic drugs, over the decade, the most significant and most preferred being metformin (Rojas and Gomes, 2013). Gastrointestinal side effects such as abdominal discomfort, anorexia, bloating and diarrhoea are adverse side effects associated with its therapy. This may be due to its associated decreased intestinal glucose absorption (Ikeda et al., 2000). Due to high profiles of adverse side effects associated with synthetic anti-hyperglycaemic agents, there is a need to develop improved alternatives with less or no net side effects for the management of diabetes, by exploring potentials offered by traditional phytotherapies (Akolade et al., 2014). There is a growing interest in herbal remedies that play important roles in the management of diabetes mellitus by Traditional Medicine Practitioners (TMPs).

Heliotropium indicum is considered one of the important herbs prescribed by TMPs for the treatment of diabetes mellitus in North Central Nigeria (Atawodi et al., 2014). It belongs to the family Boraginaceae (Burkhill, 1985). It is found in both tropical and non-tropical regions. It is usually associated with moist rich soils of the lowland tropics near rivers and lakes, on the roadsides and also in waste places. It is also commonly found in moist sandy soils or shallow swamps (Holm et al., 1997). In Nigeria it is referred to as "Agogo Igun" or "Ogbe Akuko" by the Yorubas (South west, Nigeria) and Kalkashin or korama by the Hausas (Northern Nigeria).

Decoctions from different parts of the plant are used as medicine by TMPs in many parts of Africa for treatment of fever, urticaria, ulcers, wounds, localized inflammation, gonorrhoea, ringworm, AND rheumatism (Ige, 2011; Nordeng et al., 2013; Atawodi et al., 2014). Antibacterial (Das, 2011), anti-inflammatory (Srinivas et al., 2000), antituberculosis (Machinan et al., 2005), anti-proliferative (Moongkarndi et al., 2004), gastro protective activity (Adelaja et al., 2008), wound healing (Reddy et al., 2002) and immune-stimulant (Ashoka et al., 2009) of the extracts from different parts of the plant have been reported in literature.

Aqheel et al. (2013) and Mohammed et al. (2014) showed that the methanolic extract of root and the whole plant have significant antihyperglycaemic activity in chemical-induced diabetic rat models. The extensive medicinal use of the aqueous broth of $H$. indicum leaves for management of diabetes and its secondary complications especially dyslipidemia by TMPs in Nigeria is yet to be established by adequate scientific data. Thus, in furtherance of the current investigations of medicinal plants used in the management of diabetes in Nigeria, the hereby study was carried out to evaluate the antidiabetic potentials of the aqueous extract from the leaves of $H$. indicum.

\section{Materials and Methods}

\section{Plant materials, chemicals and reagents}

Fresh leaves of Heliotropium indicum were obtained from a vegetable farm in Ilorin, Kwara State. Identification was carried at the herbarium of the Plant Biology Department of the University of Ilorin, Ilorin, Nigeria, where voucher specimen (UIH015) was deposited. Alloxan monohydrate was procured from Sigma Chemical Company, St. Louis, Mo, USA. Glucose, cholesterol, triglycerides and high density lipoproteincholesterol assay kits used were products of Randox Laboratories Ltd., Antrim, UK. All other chemicals used were of analytical / research grades.

\section{Preparation of the extracts}

The fresh leaves $(200 \mathrm{~g})$ of $H$. indicum were pulverized and soaked in distilled water $(1,000 \mathrm{ml})$. The pulverized leaf juice was left to settle for about five hours and thereafter sieved twice using muslin cloth. This was done basically to simulate the method used locally by TMPs in Ilorin metropolis, Kwara State, Nigeria. The slightly greenish brown juice obtained was lyophilized, labelled HILA in air-tight container and stored under refrigeration.

\section{Phytochemicalprofiles}

Phytochemical analyses of the HILA extract were carried out on the aqueous extracts to identify the constituents using procedures employed by Njoku and Obi (2009).

\section{Experimental animals}

Albino rats (Rattus norvegicus) of average weight of 110.88 $\pm 5.33 \mathrm{~g}$ were obtained from the animal house of the Department of Biochemistry, University of Ilorin, Ilorin, Kwara State. They were acclimatized for two weeks to standard laboratory housing conditions. The research adheres strictly and conforms to the Principles of Laboratory Animal Care (NIH Publication No. 85-23, 1996). The research protocols were requested to and approved by Department of Biochemistry, University of Ilorin, Ilorin, Nigeria.

\section{Dosage determination}

Ethno-botanical survey and personal communications with TMPs showed that approximately $250 \mathrm{ml}$ of the extracted juice is taken once a day for management of diabetes by a patient of $70 \mathrm{~kg}$ average weight, while obese patients are given same volume two-three times daily. However 1,000 $\mathrm{ml}$ of the juice, after freeze-drying yielded $8.46 \mathrm{~g}$ of HILA extract. This implies that $250 \mathrm{ml}$ is likely to contain $2.11 \mathrm{~g}$ of the extract. From this extrapolation, a dosage of $30 \mathrm{mg} / \mathrm{kg}$ b. wt. was adopted to ascertain the acclaimed antihyperglycaemic activity of the extract.

\section{Animal grouping and extract administration}

Fifty (50) rats of both sexes (housed separately) were used. They were allowed access to standard rat pellets and water $a d$ libitum, except at about $12 \mathrm{~h}$ before the measurement of fasting blood glucose (FBG; when the feeds were temporarily withdrawn). The animals were randomly selected into five groups of ten animals each as follows: 
416

1. NC: Normal Control (normoglycaemic rats receiving $1 \mathrm{ml}$ of distilled water)

2. DC: Non-Treated Control (hyperglycaemic rats receiving $1 \mathrm{ml}$ of distilled water)

3. DR: Hyperglycaemic rats treated with reference drug (14.2 mg/kg b. wt Metformin)

4. DHi30: Hyperglycaemic rats treated with $30 \mathrm{mg} / \mathrm{kg}$ b.wt. of HILA extract

5. DHi75: Hyperglycaemic rats treated with $75 \mathrm{mg} / \mathrm{kg}$ b.wt of HILA extract

\section{Induction of experimental hyperglycaemia}

Chemical induction of "hyperglycaemia", the main feature of diabetes mellitus, was done using the method employed by Sharma et al. (2010) with little modification as illustrated below. Animals were fasted for $12 \mathrm{~h}$ and then were subjected to a single intra-peritoneal injection of alloxan monohydrate, 150 $\mathrm{mg} / \mathrm{kg} \mathrm{b}$. wt, freshly dissolved in normal saline solution. A fifth of the rats were also given normal saline to serve as normoglycaemic control. Fasting blood glucose was determined using multicare-in multiparameter diagnostic device (Biochemical Systems International, Arezzo-Italia) and compatible strips $48 \mathrm{~h}$ after alloxan injection. Rats showing FBS above $250 \mathrm{mg} / \mathrm{dl}$ and sustained hyperglycaemia for the next $72 \mathrm{~h}$ (5 days after alloxan induction) were considered diabetic and used in the study.

\section{Glycaemic studies}

FBG levels of all experimental rats were determined as described above prior to treatment and after 2, 4, 8, 12 and 14 days of administration of metformin and HILA extract by withdrawing blood from the rats' caudal vein.

\section{Preparation of serum and tissues homogenates}

The rats were anaesthetized, sacrificed and blood was collected. The sera were collected and used for lipid profile analyses. Also, sacrificed carcasses were dissected; the liver and pancreas were excised. The pancreas was fixed in $10 \%$ formalin for histological examination. The livers were weighed, rinsed and homogenized in ice cold $50 \mathrm{mM}$ Tris / $\mathrm{HCl}$ buffer $\mathrm{pH} 7.5$ (Ugochukwu and Babady, 2002) containing Triton x-100 at a final concentration of $0.5 \%$ (Muhammad et al., 2006). The homogenates were stored under refrigeration (each in a labelled specimen bottle) and used for glucose and glycogen content analyses within $24 \mathrm{~h}$.

\section{Biochemical analysis}

Serum total cholesterol (TC), triglycerides (TG) and high density lipoprotein cholesterol (HDLc) were determined spectrophotometrically by using commercially available diagnostic kits obtained from Randox Laboratories (UK). Low density lipoprotein was calculated as described by Fridelwald $e t$ al. (1972). Glycogen measurement was carried out, as described by Passoneau and Lauderdale (1974) with slight modifications. Glucosyl units were determined by enzymatic oxidation by the method described by Barham and Trinder (1972). Protein concentration was also determined (Gornall et al., 1949).

\section{Statistical analysis}

Data were expressed as the mean of three or six replicates \pm standard error of mean. One way analysis of variance followed by Turkey's post hoc test for multiple comparisons using Graph Pad prism version 5.02. Values were considered significantly significant at $\mathrm{p}<0.05$.

\section{Results}

\section{Phytochemical profiles}

Lyophilization of aqueous broth of $H$. indicum leaves afforded $8.46 \mathrm{~g}$ of HILA extract per $200 \mathrm{~g}(4.23 \% \mathrm{w} / \mathrm{w})$ of fresh plant sample. Preliminary chemical profiling revealed that the extract was predominated by alkaloids, while other classes of secondary metabolites detected and quantified included saponins, cardiac glycosides, phenols, phlobatannins and anthraquinones. Table 1 shows the quantitative analyses of some of the detected phytochemicals in decreasing order: alkaloids > saponins > cardiac glycosides > phenols > phlobatannins $\geq$ anthraquinones.

\section{Glycaemic studies}

Fig. 1 shows the antihyperglycaemic effect of the orally administered aqueous extract of $H$. indicum leaf in alloxan induced hyperglycaemic rats. There was significant $(\mathrm{p}<0.05)$ reduction in the blood glucose of the diabetic rats administered with either 30 or $75 \mathrm{mg} / \mathrm{kg} \mathrm{b}$ wt. of the extract, as well as the reference drug $(14.2 \mathrm{mg} / \mathrm{kg}$ metformin) over the course of treatment. After 14 days of treatment, normoglycaemic levels were observed in diabetic rats treated with $14.2 \mathrm{mg} / \mathrm{kg}$ of metformin and $30 \mathrm{mg} / \mathrm{kg}$ of HILA extract (above $97 \%$ reduction in hyperglycaemia were achieved), whereas about $60 \%$ reduction was observed in diabetic group treated with 75 $\mathrm{mg} / \mathrm{kg}$ b. wt. of the extract (Table 2).

\section{Hepatic glucose and glycogen}

Glucose and glycogen contents in the liver of diabetic rats treated with 30 and $75 \mathrm{mg} / \mathrm{kg} \mathrm{b}$. wt. HILA extracts and 14.2 $\mathrm{mg} / \mathrm{kg} \mathrm{b}$. wt. metformin are shown on Figs. 2 and 3. Nontreated diabetic control (DC) rats showed significant $(\mathrm{p}<$ $0.05)$ increase in hepatic glucose levels and decrease $(p<0.05)$ in glycogen content when compared to the non-diabetic control (NC) rats. The elevated glucose levels were significantly lower in diabetic rats treated either with metformin or both doses of the extract. Rats treated with $30 \mathrm{mg} / \mathrm{kg} \mathrm{b}$. wt. of HILA extract recorded significantly lower hepatic glucose contents compared to those treated with $75 \mathrm{mg} / \mathrm{kg} \mathrm{b}$. wt of the extract (Fig. 2). Also, the reference drug and extracts significantly

Table 1. Phytochemical profiles of aqueous leaf extract of Heliotropium indicum

\begin{tabular}{cc}
\hline Phytochemical & Concentration $(\mathrm{mg} / \mathrm{g})$ \\
\hline Alkaloids & $2.54 \pm 0.02$ \\
Tannins & $0.01 \pm 0.01$ \\
Phlobatannin & $0.01 \pm 0.00$ \\
Saponins & $0.28 \pm 0.01$ \\
Flavonoids & $\mathrm{ND}$ \\
Anthraquinones & $0.01 \pm 0.00$ \\
Steroids & $\mathrm{ND}$ \\
Terpenes & $\mathrm{ND}$ \\
Phenol & $0.04 \pm 0.00$ \\
Cardiac glycosides & $0.08 \pm 0.01$ \\
\hline
\end{tabular}

${ }^{*} \mathrm{ND}=$ not detected

Values are expressed as means of three replicates \pm S.E.M 
Table 2. Glucose $(\mathrm{mg} / \mathrm{dL})$ lowering effect of oral administration of aqueous leaf extracts of Heliotropium indicumand metformin in alloxan induced hyperglycaemic rats

\begin{tabular}{ccccc}
\hline & $\begin{array}{c}\text { Day }-5 \\
\text { Prior to ALX Induction }\end{array}$ & $\begin{array}{c}\text { Day 0 } \\
\text { Before Treatment }\end{array}$ & $\begin{array}{c}\text { Day 14 } \\
\text { After Treatment }\end{array}$ & $85.0 \pm 6.72^{\mathrm{a}}$ \\
Glucose Reduction
\end{tabular}

Values are expressed as mean of six replicates \pm SD and those with different superscripts along a row or column are significantly different $(\mathrm{p}<0.05)$ from each other.

$\mathrm{NC}=$ normal control; $\mathrm{DC}=$ hyperglycaemic control; $\mathrm{DR}=$ hyperglycaemic + reference drug $(14.2 \mathrm{mg} / \mathrm{kg}$ metformin $) ; \mathrm{DHi} 30=\mathrm{hyperglycaemic}+30 \mathrm{mg} / \mathrm{kg}$ b.wt HILA; DHi75 = hyperglycaemic $+75 \mathrm{mg} / \mathrm{kg}$ b.wt HILA; HILA = Heliotropium indicum leaf aqueous extract; FBG = Fasting Blood Glucose.\% Glucose reduction $=[($ Day0 - Day14) $/($ Day0 - Day-5) $] \times 100$

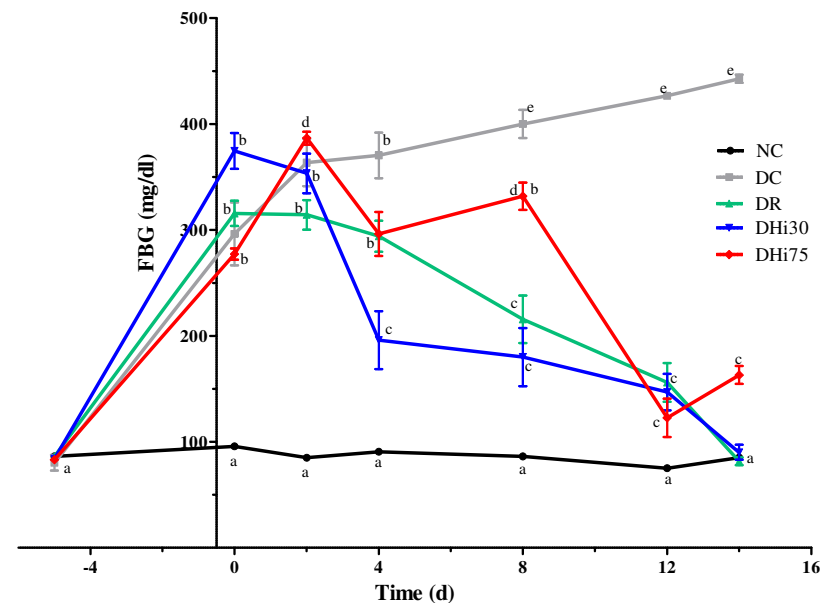

Fig. 1. Anti-hyperglycaemic effect of oral administration of aqueous leaf extract of Heliotropium indicum and metformin on glycaemia $(\mathrm{mg} / \mathrm{dl})$ in alloxan induced rats

Point values are expressed as mean of six replicates \pm S.E.M and those with different superscripts are significantly different $(\mathrm{p}<0.05)$

$\mathrm{NC}=$ normal control; $\mathrm{DC}=$ hyperglycaemic control; $\mathrm{DR}=$ hyperglycaemic + reference drug $(14.2 \mathrm{mg} / \mathrm{kg}$ metformin); DHi30 = hyperglycaemic $+30 \mathrm{mg} / \mathrm{kg}$ b.wt HILA; DHi75 = hyperglycaemic $+75 \mathrm{mg} / \mathrm{kg}$ b.wt HILA; HILA $=$ Heliotropium indicum leaf aqueous extract; FBG = Fasting Blood Glucose.

increased hepatic glycogen contents of treated diabetic rats compared to values in non-treated diabetic rats. Hepatic glycogen values determined in diabetic rats treated with 30 $\mathrm{mg} / \mathrm{kg}$ b. wt. HILA were not significantly different, whereas the other groups treated with $75 \mathrm{mg} / \mathrm{kg}$ b. wt. HILA and 14.2 $\mathrm{mg} / \mathrm{kg} \mathrm{b}$. wt. metformin recorded significantly lower glycogen contents compared to values observed in non-diabetic rats.

\section{Serum lipid profiles}

Fig. 4 depicts the effect of oral administration of aqueous extract of $H$. indicum leaf on serum total cholesterol (TC) and triglycerides (TG) of alloxan induced diabetic rats. TC and TG were significantly higher in the non-treated diabetic rats compared to non-diabetic control rats. Hyperlipidemia observed in the diabetic rats were not significantly different from values recorded in rats treated with $30 \mathrm{mg} / \mathrm{kg} \mathrm{b}$. wt. HILA extract, whereas $14.2 \mathrm{mg} / \mathrm{kg}$ b. wt. of metformin and 75 $\mathrm{mg} / \mathrm{kg} \mathrm{b}$. wt. of the extract causedsignificantly $(\mathrm{p}<0.05)$ reduction in TC and TG to values not significantly different from non-diabetic rats.

In contrast, both 30 and $75 \mathrm{mg} / \mathrm{kg} \mathrm{b}$ wt. of the extract caused significant $(p<0.05)$ increase in serum HDLc and decreased LDLc lipid fractions when compared to the nontreated diabetic rats (Fig. 5). More so, treated diabetic groups

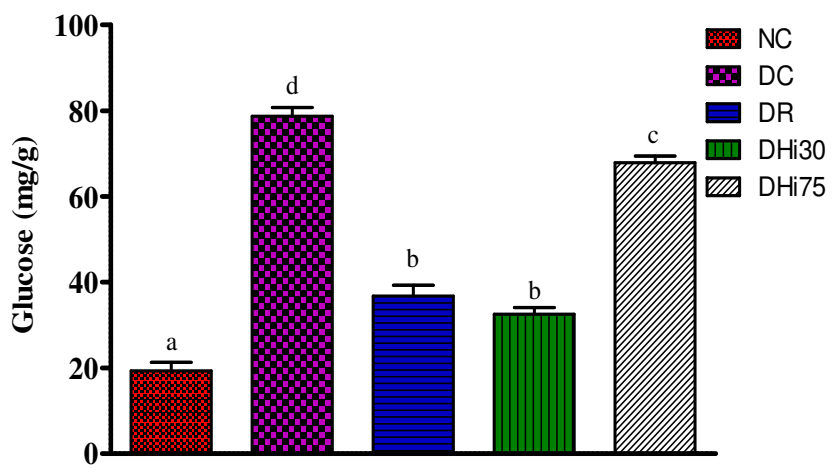

Fig. 2. Effect of oral administration of aqueous leaf extracts of Heliotropium indicum and metformin on glucose concentration in the liver homogenate $(\mathrm{mg} / \mathrm{g})$ of alloxaninduced hyperglycaemic rats

Bars are expressed as mean of six replicates \pm S.E.M and those with different are significantly different $(\mathrm{p}<0.05)$

$\mathrm{NC}=$ normal control; $\mathrm{DC}=$ hyperglycaemic control; $\mathrm{DR}=$ hyperglycaemic + reference drug (14.2 mg/kg metformin); DHi30 = hyperglycaemic $+30 \mathrm{mg} / \mathrm{kg}$ b.wt HILA; DHi75 = hyperglycaemic $+75 \mathrm{mg} / \mathrm{kg}$ b.wt HILA; HILA = Heliotropium indicum leaf aqueous extract.

recorded significantly $(\mathrm{p}<0.05)$ lower calculated artherogenic index when compared to values computed for non-treated diabetic group (Table 3 ).

\section{Pancreatic histology}

Photomicrograph of non-diabetic control rats revealed compactly arranged and evenly distributed $\beta$-cells (Fig. 6A), whereas non-treated alloxan induced diabetic rats showed severely degenerated pancreatic architecture with cellular changes, which include reduction in the $\beta$-cell counts, number of islet and atrophic changes (Fig. 6B). Micrographs of

Table 3: Effect of oral administration of aqueous leaf extracts of Heliotropium indicum and metformin on artherogenic index (LDL/HDL) in alloxan induced diabetic rats

\begin{tabular}{cc}
\hline & LDL/HDL \\
\hline NC & $0.99 \pm 0.23^{\mathrm{a}}$ \\
DC & $6.41 \pm 1.10^{\mathrm{a}}$ \\
DR & $1.14 \pm 0.07^{\mathrm{a}}$ \\
DHi30 & $0.65 \pm 0.05^{\mathrm{a}}$ \\
DHi75 & $1.13 \pm 0.10^{\mathrm{a}}$ \\
\hline Values are expressed as mean of five replicates \pm SD and those with different
\end{tabular}

Values are expressed as mean of five replicates \pm SD and those with different superscripts along a column are significantly different $(\mathrm{p}<0.05)$ from each other. $\mathrm{NC}=$ normal control; $\mathrm{DC}=$ diabetic control; $\mathrm{DR}=$ diabetic + reference drug $(14.2 \mathrm{mg} / \mathrm{kg}$ metformin $) ;$ DHi30 = diabetic $+30 \mathrm{mg} / \mathrm{kg}$ b.wt HILA; DHi75 = diabetic $+75 \mathrm{mg} / \mathrm{kg}$ b.wt HILA; HILA = Heliotropium indicum leaf aqueous extract. 
418

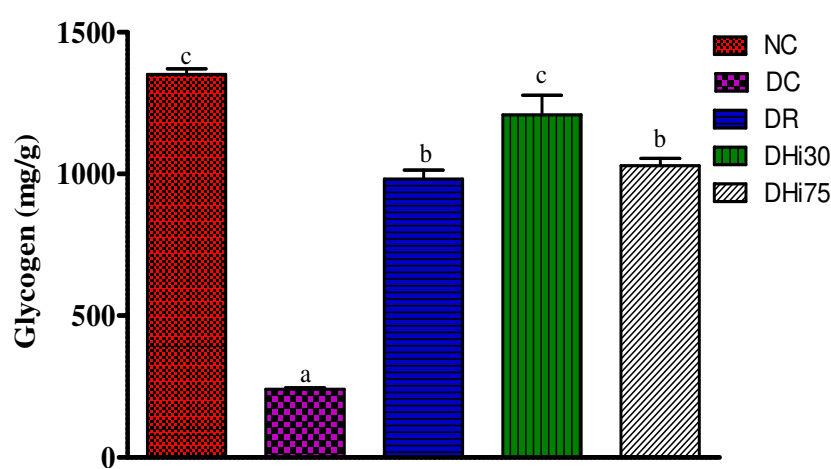

Fig. 3. Effect of oral administration of aqueous leaf extracts of Heliotropium indicum and metformin on glycogen content in the liver homogenate $(\mathrm{mg} / \mathrm{g})$ of alloxan-induced diabetic rats Bars are expressed as mean of six replicates \pm S.E.M and those with different are significantly different $(\mathrm{p}<0.05)$.

$\mathrm{NC}=$ normal control; $\mathrm{DC}=$ hyperglycaemic control; $\mathrm{DR}=$ hyperglycaemic + reference drug (14.2 mg/kg metformin); DHi30 = hyperglycaemic $+30 \mathrm{mg} / \mathrm{kg}$ b.wt HILA; DHi75 = hyperglycaemic $+75 \mathrm{mg} / \mathrm{kg}$ b.wt HILA; HILA $=$ Heliotropium indicum leaf aqueous extract.

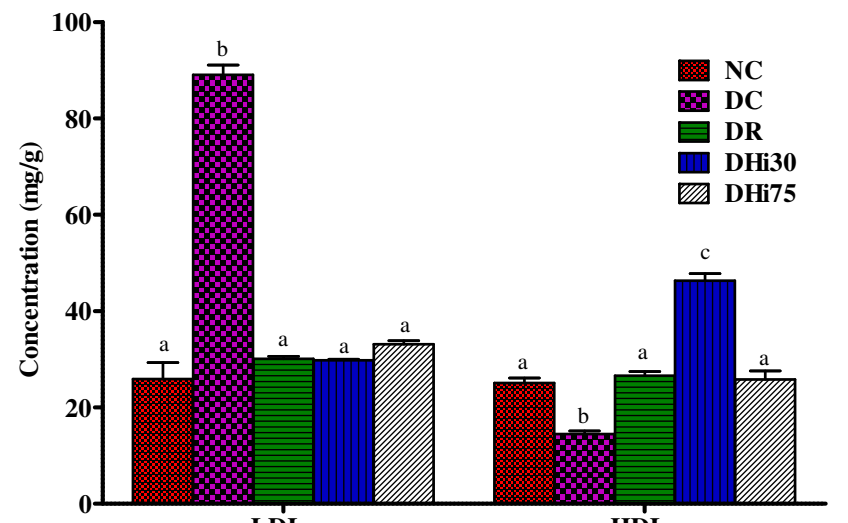

LDLc

HDLc

Fig. 5. Effect of oral administration of aqueous leaf extracts of Heliotropium indicum and metformin on serum lipoprotein cholesterol fractions $(\mathrm{mg} / \mathrm{dl})$ in alloxan induced diabetic rats Bars are expressed as mean of six replicates \pm S.E.M and those with different are significantly different $(\mathrm{p}<0.05)$.

$\mathrm{NC}=$ normal control; $\mathrm{DC}=$ hyperglycaemic control; $\mathrm{DR}=$ hyperglycaemic + reference drug $(14.2 \mathrm{mg} / \mathrm{kg}$ metformin $) ; \mathrm{DHi} 30$ = hyperglycaemic $+30 \mathrm{mg} / \mathrm{kg}$ b.wt HILA; DHi75 = hyperglycaemic $+75 \mathrm{mg} / \mathrm{kg}$ b.wt HILA; HILA $=$ Heliotropium indicum eaf aqueous extract; $\mathrm{HDL}=\mathrm{H}$ High density lipoprotein cholesterol LDLc $=$ Low density lipoprotein cholesterol.

diabetic rats treated with $30 \mathrm{mg} / \mathrm{kg} \mathrm{b}$ wt or $75 \mathrm{mg} / \mathrm{kg} \mathrm{b}$. wt. HILA extracts demonstrated mildly to moderately degenerated pancreas with distorted architecture of lesser degeneration (Fig. 6C-D) compared to the non-treated diabetic slide.

\section{Discussion}

Hyperglycaemia was achieved within 48 hours of induction with alloxan monohydrate and the elevated blood glucose level persisted for five days post-induction. This is in agreement with the summation of Lenzen (2008) saying that the last phase during which complete degranulation and loss of the integrity of the beta cells takes place occurs within 24$48 \mathrm{~h}$ after administration of the alloxan, resulting in sustained hyperglyecmia. Treatment of alloxan-induced rats with oral

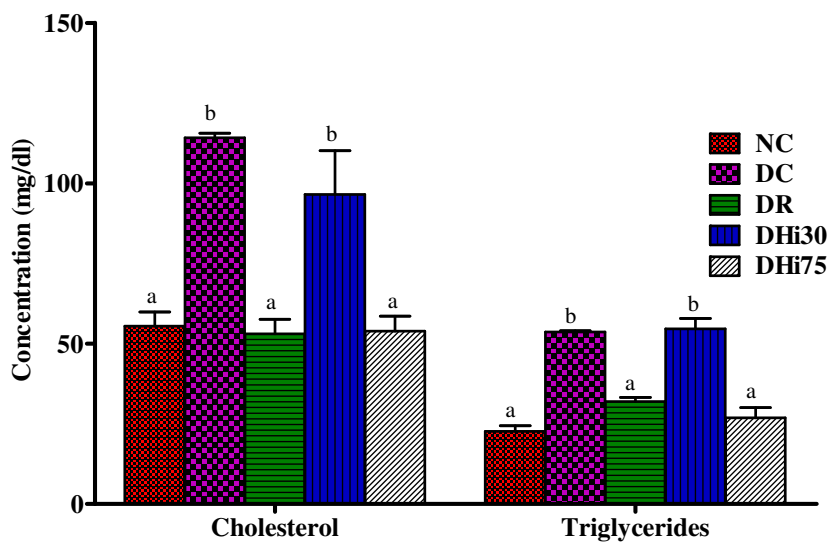

Fig. 4. Effect of oral administration of aqueous leaf extracts of Heliotropium indicum and metformin on serum cholesterol and triglycerides of alloxan-induced diabetic rats

Bars are expressed as mean of six replicates \pm S.E.M and those with different are significantly different $(\mathrm{p}<0.05)$.

$\mathrm{NC}=$ normal control; $\mathrm{DC}=$ hyperglycaemic control; $\mathrm{DR}=$ hyperglycaemic + reference drug (14.2 $\mathrm{mg} / \mathrm{kg}$ metformin); DHi30 = hyperglycaemic $+30 \mathrm{mg} / \mathrm{kg}$ b.wt HILA; DHi75 = hyperglycaemic $+75 \mathrm{mg} / \mathrm{kg}$ b.wt HILA; HILA $=$ Heliotropium indicum leaf aqueous extract.

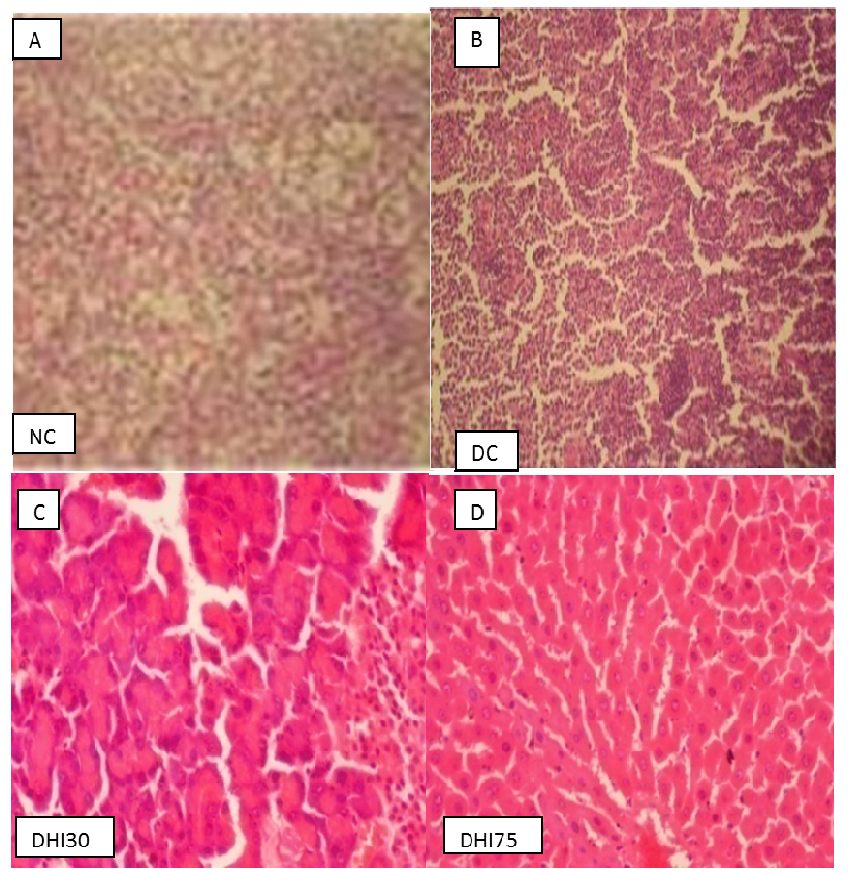

Fig. 6. Photomicrographs $(\mathrm{x} 100)$ of the pancreas of normoglycaemic rats (A), non-treatedhyperglycaemic rats (B), hyperglycaemic rats treated with $30 \mathrm{mg} / \mathrm{kg} \mathrm{b}$ wt of Heliotropium indicum (C) and hyperglycaemic rats treated with $75 \mathrm{mg} / \mathrm{kg}$ b wt of Heliotropium indicum (D)

administration of 30 and $75 \mathrm{mg} / \mathrm{Kg} \mathrm{b}$. wt. aqueous extract of $H$. indicum leaf caused significant reduction in hyperglycaemia after 4 and 12 days of administration respectively. Normoglycaemic baseline level was achieved in rats treated with the $30 \mathrm{mg} / \mathrm{kg} \mathrm{b}$. wt. of the extracts after 14 days of administration. This implies that the extract effects normalized fasting blood glucose and established the local use of the leaf extract for the management of diabetes. 
The antihyperglycaemic effect of the extract may be attributed to its secondary metabolite profile. The medicinal worth of plants lies in their phytochemical constituents which produce definite physiological action. The aqueous extract of H. indicum Linn leaf contained alkaloids $>$ saponins $>$ phenols $>$ tannins $>$ anthraquinones, in decreasing abundance among others found in trace amount. This profile is similar to that reported by other researchers (Akinlolu et al., 2008; Geroge $e t$ al., 2012). Phenols and saponins are known for their antioxidant activities and in addition, they have also been reported to inhibit $a$-amylase and suppress postprandial hyperglycaemia (Michalak, 2006). Also, tannins are well known for their precipitating effect on proteins, and they also have effects on carbohydrates, particularly starch (Schofield $e t$ al., 2001). Interaction between tannins and membrane proteins of the intestinal mucosal cells changes the permeability of the intestinal wall, resulting in a reduction of the intestinal absorption (Silanikove, 2000). This may be an important factor in reducing the influx of glucose from the gastrointestinal tract. This effect modulated by tannins may contribute to the overall antihyperglycaemic effect of the aqueous extract of $H$. indicum leaf.

Alkaloid is the major secondary metabolite quantified in aqueous leaves extract of $H$. indicum. Previous studies have attributed the glucose lowering and antihyperglycaemic effects of plant extracts to their alkaloid contents (Ignacimuthu and Amalraj, 1998). The alkaloid fraction of the H. indicum aqueous extract has been reported to contain pyrolizidine alkaloids and their N-oxides (Pandey et al., 1996; Singh et al., 2005; Souza et al., 2005). These compounds are known to be hepatotoxic, however, there is a wealth of evidences on therapeutic uses of the extract of $H$. indicum such as wound healing activity (Reddy et al., 2002; Suresh et al., 2002; Muthu et al., 2006); anti-inflammatory activity (Srinivas et al., 2002; Abubakar et al., 2007; Betanabhatla et al., 2007) and gastroprotective active activity (Akinlolu et al., 2008). These data suggest that the alkaloid component of the extract may contain some more beneficial compounds that may account for its antihyperglycaemic activity.

In the hereby study, histological examination of the pancreas showed massive destruction of $\beta$-cells of the islets of langerhans caused by induction of alloxan. This can occur through the formation of reactive oxygen species (Szkudelski, 2001). Treatment of alloxan induced rats with HILA caused improved pancreatic architecture of lesser degeneration. This amelioration of alloxan toxicity further affirmed the beneficial potentials of the extract.

The selective destruction of $\beta$-cells of the islets of langerhans caused by alloxan results in marked decreased in insulin levels (Rohilla et al., 2012) and hence a reduction in hepatic glycogen in diabetic rats (Sharma et al., 2010). Glycogen is the primary intracellular storable form of glucose in mammalian tissues, especially the liver and its concentration in such tissues is a direct indication of insulin activity. Therefore, hepatic glycogen concentration may be considered as one of the best parameter for assessing antihyperglycaemic activity of a drug (Grover et al., 2000). In the present study, the observed reduction in hepatic glycogen of diabetic rats is in accordance with the findings of Ahmed et al. (2006) and Thambi et al. (2008). Many researchers have ascribed hepatic glycogen reduction to the loss of glycogen synthetase activating system
(Huang et al., 2006) and/or increased activity of glycogen phosphorylase and glucose -6- phosphatase (Ahmaed et al., 2006) in diabetic subjects. The depressed hepatic glycogen levels were elevated in diabetic rats treated with the aqueous extract of $H$. indicum. There is likelihood that the extract contains bioactive principles that may promote the conversion of the inactive form of glycogen synthetase to the active form and the conversion of the active form of glycogen phosphorylase to its inactive form or inhibition of glucose -6phosphatase. Any of these effects will enhance conversion of blood glucose into glycogen.

In diabetes mellitus, the composition and amount of the different lipoprotein particles are altered as a result of the hyperglycaemia induced-dyslipidaemia. The key features of this dyslipidaemia are the elevated levels of cholesterol and triacylglycerols, the reduced levels of HDL cholesterol, and the increased number of LDL particles (ADA, 2009). In addition to the glucose lowering activities of aqueous extract of $H$. indicum, the extracts also ameliorates dyslipidemia observed in diabetic rats. Many phytochemicals such as phenols, tannins, saponins and alkaloids have been implicated in the antidyslipidemic effects elicited by plant extracts by virtue of their proven antioxidant properties (Aly et al., 2010), or through demonstrated insulin-like effect (Khushbaktova et al., 2001).

Saponin, which is one of the major constituents of $H$. indicum, is known to elicit serum cholesterol lowering activity and may be classified as a direct antidyslipidemic agent, in contrast indirect antidyslipidemic agents like the sulphonylureas that act through the stimulation of pancreatic beta cells increase insulin release (Abdel-Hassam et al., 2000; Chang-Yong et al., 2010). This is more so because saponins are known for their detergent properties; they have the possibility of forming micelles with lipids and can interact with cholesterol to form soluble complexes (Mitra et al., 2000).

The elevated cardioprotective HDL-C concentration in rats treated with the extract reflects afflux of cholesterol from the tissues, the first step in reverse cholesterol transport from the peripheral tissues to the liver. The antioxidant and artherogenic activities of HDL-C are enhanced when its circulating level is increased. Improved artherogenic index of diabetic rats treated with the HILA extract is in line with the finding of George et al. (2012), who reported that aqueous extract of $H$. indicum possesses stimulatory effects (comparable to the stimulatory effect of acetylcholine) on the muscarinic and nicotinic receptors. Muscarinic-receptor stimulation by acetylcholine increases arterial flow (Steif et al., 1989) and its activity on the myocardium results in a negative ionotropic and chonotropic effect that contributes immensely to reducing blood pressure and total peripheral resistance. Therefore the current study further gives basis for the traditional use of $H$. indicum for treatment of not only diabetes, but also its associated secondary complications such as dyslipidemia and hypertension.

\section{Conclusions}

It can be concluded from the hereby study that Heliotropium indicum does not only possess antihyperglycaemic potentials, for which it is prescribed by TMPs, but also possess antidyslipidemic activities. The aqueous 
420

leaf extract of $H$. indicum can therefore be explored for the management of diabetes and its associated complications.

\section{Acknowledgements}

The authors acknowledge the late memory of Professor Muhammed, N.O. of the Federal University, Dutsin-Ma, Nigeria, for his mentorship, supervision and support.

\section{References}

Abdel-Hassan IA, Abdel-Barry JA, Mohammed ST (2000). The hypoglycaemic and antihyperglycaemic effect of Citrullus colocynthis fruit aqueous extract in normal and alloxan diabetic rabbits. Journal of Ethnopharmacology 71:325-330.

Abubakar MS, Musa AM, Ahmed A, Hussaini IM (2007).The perception and practice of traditional medicine in the treatment of cancers and inflammations by the Hausa and Fulani tribes of Northern. NigeriaJournal ofEthnopharmacology 111(3):625-629.

Adelaja AA, Ayoola MD, Otulana JO, Akinola OB, Olayiwola AA, Ejiwumi $A B$ (2008). Evaluation of the histo-gastroprotective and antimicrobial activities of Heliotropium indicum Linn (Boraginaceae). Malaysian Journal of Medical Sciences 15(3):22-30.

Adisakwattana S, Roengsamran S, Hsu WH, Yibchok-anun S (2005). Mechanism of antihyperglycaemic effect of $p$-methoxicinnamic acid in normal and streptozotocin-induced diabetic rats. Life Sciences 78:406412.

Ahmed OM, Abdel-Hamid H, Bastawy M, Hasona NA (2006). Antihyperglycaemic effects of Plantago ispaghula seeds aqueous extracts in diabetic and hypercholesterolemic rats. Journal of Egyptian German Society ofZoology 51:371-393.

Akinlolu AA, Ayoola MD, Otulana JO, Akinola OB, Abimbola O, Ejiwunmi $\mathrm{AB}$ (2008). Evaluation of the histo-gastroprotective and Antimicrobial activities of Heliotropium indicum Linn. (Boraginaceae). Malaysian Journal of Medical Sciences 15(3):22-30.

Akolade JO, Usman LA, Okereke OE, Muhammad NO (2014). Antidiabetic potentials of essential oil extracted from the leaves of Hoshundia opposita Vahl.Journal of Medicinal Food 17 (10):1122-1128.

Aly HF, Ebrahim ME, Metawaa MH, Ahlam Hosni EA, Ebrahim FM (2010). In vitro and in vivo evaluation of the antidiabetic effect of different extracts of Nepeta cataria in streptozotocin induced diabetic rats. Journal of American Science 6(10):364386.

America Diabetes Association. Adapted from American Diabetes Association (2009). Diagnosis and classification of diabetes mellitus. Diabetes Care 3(1):62-67.

Aqheel MA, Janardhan M, Durrai vel S (2013). Evaluation of the antihyperglycaemic activity of methanolic extract of root of Heliotropium indicum in streptozotocin and alloxan induced diabetic rats. Indian Journal of Research in Pharmacy and Biotechnology 1:707710.

Ashoka M, Shasty CS, Sridevi K, Gopkumar P (2009). Stimulation of immune function activity of the extract of Heliotropium indicum leaves. Internetional Journal of Pharmacology 7:1.

Atawodi SE, Olowoniyi OD, Obari MA, Israel OI (2014). Ethnomedical survey of Adavi and Ajaokuta Local Government Areas of Ebiraland, Kogi State, Nigeria, Annual Research \& Review in Biology 4(24):4344 4360.

Barham D, Trinder P (1972). An improved colour reagent for the determination of blood glucose by the oxidase system. Analyst 97(151):142-145.

Betanabhatla KS, JasminSajni R, Karthik R, Raamamurthy J, Christina AJM, Sasikumar S (2007). Antiinflammatory and antinociceptive activities of Heliotropium indicum Linn in experimental animal models. Pharmacology online 3:438-445.

Burkhill HM (1985). The useful plants of tropical West Africa, vol. 1 pp 293-295.

Cade WT (2008). Diabetes-related microvascular and macrovascular diseases in the physical therapy setting. Physical Therapy 88(11):13221335.

Chang-yong Y, Jing W, Yuan Z, Li S, Xing J, Zhen-guo X, Nan L, Liu Z, Zhong-hua C (2010). Anti-diabetic effects of Panaxnoto ginseng saponins and its major anti-hyperglycaemic components. Journal of Ethnopharmacology 130:231-236.

Das PK (2011). Antibacterial activity of leaf extracts of Heliotropium indicum Linn. Life Sciences Leaflets 20:904907.

Fridelwald WT, Levy RI, Fredrickson DS (1972). Estimation of the concentration of low-density lipoprotein cholesterol in plasma, without use of the preparative ultracentrifuge. Clinical Chemistry 18:461-470.

George AK, Alex B, Patrick A, Elvis OA, Alfred KA (2012). Investigating the sight of action of an aqueous extract of Heliotropium indicum Linn (Boraginaceae) on smooth Muscles. Research Journal of Pharmacolology 6(1):12-19.

Goldberg IJ (2001). Diabetic dyslipidemia: causes and consequences. The Journal ofClinical Endocrinology \& Metabolism 86 (3):965-971.

Gornall AG, Bardawill JC, David MM (1949). Determination of serum proteins by means of Biuret reaction. Journal of Biological Chemistry 177:751-760.

Grover JK, Vat V, Rathi SS (2000). Anthihypergycaemic effect of Eugenia jambolana and Tinospora cordifolia in experimental diabetes and their effects on key metabolic enzymes involved in carbohydrate metabolism. Journal of ethnopharmacology 73:461-470.

Guthrie DW, Guthrie RA (2009). Management of diabetes mellitus: A Guide to the Pattern Approach. Springer Publishing Company $\left(6^{\mathrm{h}} \mathrm{ed}\right)$, New York.

Holm L, Del Y, Holm E, Panchon T, Herberger T (1997). World weeds: Natural Histories and Distributions. John Wiley and Sons Inc, New York.

HuangX, Vaag A, Hanson M, WengJ, Laurila E, Goop L (2006). Impaired insulin stimulated expression of the gycogen synthase gene in skeletal muscle of type II diabetic patients acquired rather than inherited.Journal ofClinical Endocrinology and Metabolism 85:15841590.

Ige OE (2011). Preliminary investigations on the ethnomedicinal plants of Akoko division, South West Nigeria. Global Journal of Health Science 3(2):84.

Ignacimuthu S, Amalraj T (1998). Antidiabetic and antihyperlipidemic effect of Zizyphus jujube in alloxan-induced diabetic rats. Indian Journal of Pharmacology 30:107-108. 
Ikeda T, Iwata K, Murakami H (2000). Inhibitory effect of metformin on intestinal glucose absorption in perfused rat intestine. Biochemical Pharmacology 59:887-890.

International Diabetes Federation (2014). Diabetes atlas (6th ed.). Brussels, Belgium 1-155.

KhushbaktovaZA, FaizievaSKH, Syrov VN, Yuldashev MP, BatirovEKH, Mamatkhanov AU (2001). Isolation, chemical analysis, and study of the hypolipidemic activity of the total flavonoid extract from Thermopsis altherniaflora. Pharmaceutical Chemistry Journal 35:155-158.

Lenzen S (2008). The mechanisms of alloxan and streptozotocin-induced diabetes. Diabetologia 51:216-226.

Li WL, Zheng HC, Bukuru J, Kimpe DN (2004). Natural medicines used in the traditional Chinese medical system for therapy of diabetes mellitus. Journal of Ethnophamacology 92:1-21.

Machinan T, Korth J, Boonsom L, Saisunee L, Stephen G (2005). Composition and antituberculosis activity of the volatile oil of Heliotropium indicum Linn. Growing in Phitsanulok, Thailand Flavour Fragrance Journal 21(2):265-267.

Michalak A (2006). Phenolic compounds and their antioxidant activity in plants growing under heavy metal stress. Polish Journal of Environmental Studies 15(4):523-530.

Mitra S, Dungan SR (2000). Micellar properties of Quillaja saponin.2.Effect of solubilized cholesterol on solution properties. Colloids and Surfaces B. Biointerfaces 17:117-133.

Mohammad SA, Abdul Nabi S, Marella S, Thandaiah KT, Venkateshwarulu M, Kumar J, Rao CA (2014). Phytochemical screening and antihypergycaemic activity of Heliotropium indicum whole plant in Streptozotocin induced diabetic rats. Journal of Applied Pharmaceutical Science 4(12) 065-071.

Moongkarndi P, Kosem N, Luanratana O, Jongsomboonkusol S, Pongpa N (2004). Antiproliferative activity of Thai medicinal plant extracts on human breast adenocarcinoma cell line. Fitoterapia 75:375-377.

Muhammad NO, Oloyede OB, Yakubu MT (2006). Effect of Terminalia catappa seed meal-based diet on the alkaline and acid phosphatases activities of some selected rat tissues. Recent Progress in Medicinal Plants 13:272-279.

Muthu C, Ayyanar M, Raja, Ignacimuthu S (2006). Medical plants used by traditional healers in Kancheepuram District of Tamil Nadu, India. Journal of Ethnobiology and Ethnomedicine 2:43.

National Research Council: Institute of Laboratory Animal Resources (1996). Guide for the Care and Use of Laboratory Animals, Revised. National Academy Press, Washington DC 85:23

Njoku OV, Obi C (2009). Phytochemical constituents of some selected medicinal plants. African Journal of Pure and Applied Chemistry 3(11):228-233.

Nordeng H, Al-Zayadi W, Diallo D, Ballo N, Paulsen BS (2013). Traditional medicine practitioners' knowledge and views on treatment of pregnant women in three regions of Mali. Journal of Ethnobiology andEthnomedicine 9:67.

Oyagbemi AA, Salihu M, Oguntibeju OO, Esterhuyse, AJ, Farombi EO (2014). Some selected medicinal plants with antidiabetic potentials. Antioxidant, Antidiabetic Agents and Human Health, INTECH 4:95-113.
Pandey DP, Singh JP, Roy R, Singh VP, Pandey VB (1996). Constituents of Heliotropium indicum. Oriental Journal ofChemistry 12:321-322.

Passoneau JV, Lauderdale VR (1974). A comparison of three methods of gycogen measurement in tissues. Analytical Biochemistry 60:405-412.

Reddy JS, Rao PR, Reddy MS (2002). Wound healing effects of Heliotropium indicum, Plumbagozeylanicum and Acalyphaindica in rats. Journal of Ethnopharmacology 79(2):249-251.

Rohilla A, Ali S (2012). Alloxan induced diabetes: mechanisms and effects. International Journal of Research in Pharmaceutical and Biomedical Sciences 3(2):819-823.

Rojas LBA, Gomes MB (2013). Metformin: an old but still the best treatment for type 2 diabetes. Diabetology and Metabolic Syndrome 5:6.

Schofield P, Mbugua DM, Pell AN (2001). Analysis of condensed tannins: a review. Animal Feed Science and Technology 91:21-40.

Sharma N, Garg V, Paul A (2010). Antihyperglycaemic, antihyperlipidemic and antioxidative potential of Prosopis cineraria bark. Indian Journal of Clinical Biochemistry25(2):193-200.

Shin HJ, Kim JH, Yi JH, Han SW, Kim HJ (2012). Polyuria with the concurrent manifestation of Central Diabetes Insipidus (CDI) \& type 2 Diabetes Mellitus (DM). Electrolyte \& Blood Pressure 10(1):26-30.

Silanikove N (2000). The physiological basis of adaptation in goats to harsh environments. Small Ruminant Research 35:181-193.

Singh JP, Pandey DP, Pandey MB, Singh A, Singh R (2005). Alkaloids of Heliotropium indicum. Journal of Indian Chemical Society 82:175-176.

Souza JSN, Machado LL, Pessoa ODL, Braz-Filho R, Overk CR, Cassia R, Yao P, Cordell GA, Lemos TLG (2005). Pyrrolizidine alkaloids from Heliotropium indicum. Journal of Brazillian Chemical Society 16:14101414.

Srinivas K, Rao MEB, Rao SS (2000). Anti-inflammatory activity of Heliotropium indicum Linn and Leucas aspera spreng. in albino rats. Indian Journal of Pharmacology 32:37-38.

SteifC, Diederichs W, Bernard F, Bosch R, AboseifS, Lue TF, Tanagho EA (1989). Possible role of acetylcholine as a neurotransmitter in canine penile erection. Urologia Internationalis 44:357-363.

Strojek K (2003). Features of macrovascular complications in type 2 diabetic patients. Acta Diabetologica 40:334337.

Suresh JR, Rao PR, Reddy MS (2002). Wound healing effects of Heliotropium indicum, Plumbagozeylanicum and Acalpha indicain rats. Journal of Ethnopharmacology 79(2):249-251

Szkudelski T (2001). The mechanism of alloxan and streptozotocin action B cells of the rat pancreas. Physiology Research 50(6):536-546.

Thambi P, Sabu MC, Jolly C (2008). Acute toxicity and diuretic activity of M. indica L. bark extract. Pharmacology 103:111.

Ugochukwu NH, Babady NE (2002). Antioxidant effects of Gongronema latifolium in hepatocytes of rat models of non-insulin dependent diabetes mellitus. Fitoterapia 73:612-618.

Wild S, Roglic G, Green A, Sicree R, King H (2004). Global prevalence of diabetes estimates for the year 2000 and projections for 2030. Diabetes Care 27:1047-1053. 